\title{
OUTBREAKS OF HUMAN TRICHINELLOSIS CAUSED BY CONSUMPTION OF DOG MEAT IN CHINA
}

\author{
CUI J.* \& WANG Z.Q.*
}

\begin{abstract}
Summary :
Dog meat has become an important source of Trichinella infection for humans in China. The first documented outbreak of human trichinellosis resulting from the consumption of dog meat occurred in China in 1974. Until 1999, the outbreaks with this source of infection occurred mostly in Northeast of China 181 cases in five outbreaks in Jilin and two in Liaoning), Beijing (six cases) and Henan provinces (two cases). The epidemiological surveys were performed in nine Provinces or Autonomous Regions of China among 19,662 dogs samples. Dogs trichinellosis prevalence ranged from $7 \%$ in Henan to $39.5 \%$ in Heilongiiang, with an overall prevalence of $21.1 \%$. Based on random amplified polymorphic DNA fingerprint (RAPD), some dog isolates of Heiloniiang and Jilin provinces were recently identified as Trichinella nativa, suggesting that this parasite is widely distributed among dogs in Northeast of China, while Trichinella spiralis in swine appears to be a common parasite throughout China. Since the Trichinella larvae in dog meat is resistant to freezing, caution should be paid to the consumption of dog meat even if it had been frozen.
\end{abstract}

KEY WORDS : trichinellosis, T. spiralis, T. nativa, dog meat, prevalence, China.

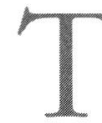
Trichinellosis is an important public health problem in China. Since the first patient with trichinellosis was reported in Xizang (Tibet) Autonomous Region (Huang, 1965), many outbreaks and sporadic cases have been reported in this country (Cud et al., 1997; Wang et al., 1997). Only in Yunnan province in Southwest of China, 442 outbreaks of trichinellosis, with 20,334 cases and 217 deaths, were recorded from 1964 to 1999 (Pang et al., 1999). The majority of cases were caused by the ingestion of raw or inadequately cooked pork products (Wang et al., 1998). Therefore, pork are usually examined at abattoirs to detect Trichinella larvae. However, outbreaks of trichinellosis associated with eating dog meat have been reported regularly but there is not nationwide epidemiological data about the prevalence of canine trichinellosis. Therefore, in this short report the authors review the epidemiological data of the outbreaks of human trichinellosis associated with dog meat consumption and canine trichinellosis in China. The materials used were the literature published up to date in China.

\footnotetext{
* Department of Parasitology, Henan Medical University, Zhengzhou 450052, China. Tel: (86) 371-6975190 - E-mail: jingcui@371.net
}

\section{OUTBREAKS OF TRICHINELLOSIS ASSOCIATED WITH EATING DOG MEAT}

1 The first outbreak of trichinellosis resulting from the consumption of dog meat occurred during November 1974, with nine cases, in Jilin province. Between 1974 and 1999, seven outbreaks related to this source of infection occurred in the Northeast of China (81 cases ), but a small outbreak (six cases) also occurred in Beijing in 1987 and Henan (two cases) in 1998 (Table I).

\section{PREVALENCE OF CANINE TRICHINELLOSIS IN CHINA}

$\mathrm{B}$ y direct microscopic examination and/or artificial digestion method, the epidemiological survey on the prevalence of canine trichinellosis was carried out in nine Provinces or Autonomous Regions of China from 1950 to 1998. The prevalence differs with the regions from $0.8 \%$ to $54 \%$, but globally the infection rate may be as high as $21.3 \%$ in the dogs of these regions (Table II). Dog meats sold at markets showed similar rates of infection. In Kunming city of Yunnan province 102 dog meats were examined for Trichichella larvae and four (3.9\%) were infected (Zhang, 1985). The prevalence of canine trichinellosis differs widely in the different areas, even in the same province. The prevalence in Heilongjiang province varies from $9 \%$ to $61.8 \%$, as determined by microscopical examination of $30 \mathrm{~g}$ diaphragm muscle of dog carcasses (Yang et al., 1997; Zhou et al., 1990).

\section{IDENTIFICATION \\ OF TRICHINELLA SPECIES FROM DOGS IN NORTHEAST CHINA}

ince the Trichinella larvae were first found in swine muscle in 1881 in China (Manson,1881), it has been considered that only T. spiralis was the 


\begin{tabular}{ccclll}
\hline Outbreak & Year & No. cases & Location & Preparation of dog meat & Reference \\
\hline 1 & 1974 & 9 & Jilin & Raw & Yuan, 1980 \\
2 & 1980 & 9 & Jilin & Semi-cooked & An, 1982 \\
3 & 1981 & 33 & Jilin & Roasted & Hou et al., 1985 \\
4 & 1979 & 8 & Liaoning & Semi-cooked & Xu et al., 1989 \\
5 & 1987 & 9 & Jilin & Raw and semi-cooked & Jiang et al., 1989 \\
6 & 1987 & 8 & Jilin & Scalded & Wei \& Song, 1991 \\
7 & 1987 & 6 & Beijing & Scalded & Wang et al., 1989 \\
8 & 1989 & 5 & Liaoning & Raw & Xu et al., 1989 \\
9 & 1998 & 2 & Henan & Semi-cooked & Wang et al., 1998 \\
\hline
\end{tabular}

Table I. - Outbreaks of trichinellosis associated with dog meat consumption in China during 1974-1999.

\begin{tabular}{|c|c|c|c|c|c|}
\hline Location & Year & No. examined & No. infected & $(\%)$ & Reference \\
\hline \multirow[t]{4}{*}{ Liaoning } & 1950 & 21 & 6 & 28.6 & Chin et al., 1950 \\
\hline & 1973 & 2,705 & 349 & 12.9 & Zhang, 1983 \\
\hline & 1996 & 101 & 16 & 15.8 & Chen, pers. comm., 1999 \\
\hline & 1997 & 655 & 5 & 0.8 & Li et al., 1997 \\
\hline Jilin & 1992 & 1,375 & 135 & 9.8 & Wang \& Wang, 1992 \\
\hline \multirow[t]{4}{*}{ Heilongjiang } & 1980 & 35 & 19 & 54.3 & Wang, pers. comm., 1999 \\
\hline & 1981 & 6,231 & 2,792 & 44.8 & Yang et al.. 1997 \\
\hline & 1990 & 137 & 47 & 34.3 & Zhou et al., 1990 \\
\hline & 1996 & 950 & 47 & 4.9 & Liu et al., 1996 \\
\hline Hebei & 1996 & 4,281 & 485 & 11.3 & Liu et al., 1996 \\
\hline \multirow[t]{2}{*}{ Gansu } & 1960 & 22 & 6 & 27.2 & Liu \& Yu, 1960 \\
\hline & 1996 & 100 & 9 & 9.0 & Liu et al., 1996 \\
\hline \multirow[t]{2}{*}{ Henan } & 1977 & 2,136 & 149 & 7.0 & Deng, 1978 \\
\hline & 1983 & 21 & 2 & 9.0 & Gong, pers. comm., 1996 \\
\hline Hubei & 1998 & 43 & 8 & 18.6 & Ye et al., 1998 \\
\hline Guangxi & 1995 & 9 & 3 & 33.3 & Meng \& Wang, 1995 \\
\hline \multirow[t]{2}{*}{ Yunnan } & 1979 & 318 & 23 & 7.2 & Zheng, pers. comm., 1996 \\
\hline & 1991 & 522 & 50 & 9.6 & Yang, 1991 \\
\hline Total & & 19,662 & 4,151 & 21.1 & \\
\hline
\end{tabular}

Table II. - Prevalence of canine trichinellosis in nine Provinces or Automomous Regions of China.

aetiological agent of human and swine trichinellosis in China. All isolates of Trichinella from domestic swine in China (ISS78, 79, 80, 81, 82, 533, 534, 535) have been identified as T. spiralis by allozyme analysis (La Rosa et al., 1992) or RAPD. However, some isolates of Trichinella in dogs of Heilongiiang \& Jilin (ISS529, 530, 531, 532) were recently identified as $T$. nativa by RAPD (Liu et al., 1997; Xu, Cui et al., 1997; Xu, Liu et al., 1997). Thus, there are at least two species of Trichinella in China: T. spiralis' which appears in pigs and dogs (ISS407), probably in most parts of China and T. nativa, which has been found in dogs in the Northeast China and also in cats (ISS532). Unfortunately, no muscle biopsy from the patients during outbreaks caused by dog meat was available, it is still unknown if the implication of both species in human trichinellosis where the source of infection is dog meat.

\section{DISCUSSION}

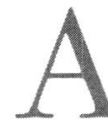

lthough canine trichinellosis was firstly reported in the Northeast of China sixty years ago (Yugawa, 1934), outbreaks of human trichinel- losis related to dog meat consumption were not recorded before the 1970s. The consumption of dog meat (particularly during the winter season) used to be quite rare in China, but increased recently especially among the Chaoxian (Korean) people located in the Northeast of China (Liaoning, Jiling \& Heilongjiang), but also among the Han race (the commonest in China). Human trichinellosis caused by eating dog meat is rare in other countries (Kim, 1991). During an outbreak of trichinellosis occurred in 1981 in Petchaboon province of Thailand, 15 dogs were examined, and eight were founded to be infected with Trichinella. In the northeastern part of Thailand, a survey showed seven infected dogs out of 421 in a dog meat market in 1981 (Khamboonruang, 1991). However, high rates of Trichinella infection have also been detected in wild dogs (prevalence of $18.3 \%$ ) or domestic dogs (prevalence of $8.9 \%$ ) in Lithuania (Rochiene, 1993) and in sledge dog of Greenland (prevalence of $71 \%$ ) (Kapel et al., 1996).

Transmission of canine trichinellosis has several origins. It was speculated that the dogs might acquire the infection mainly by eating discarded infected swine scraps in China and in Thailand. In Greenland, the 
dogs become infected by uncooked scraps from hunted polar bear and walrus, but scavenging of other dog carcasses can play an important role in the epidemiology (Kapel et al., 1996).

Trichinella larvae present in dog meat from the Northeast of China was resistant to freezing in most cases. One outbreak of trichinellosis (nine cases) occurred in Jilin in 1987 and was due to dog meat frozen outdoors from $-15^{\circ} \mathrm{C}$ to $-22^{\circ} \mathrm{C}$ for $11-39$ days (Jiang et al., 1989). Under laboratory condition, the isolates of $\mathrm{Tr}$ chinella from dogs of Heilongiiang survived at $-15^{\circ} \mathrm{C}$ for 12 months or at $-25^{\circ} \mathrm{C}$ for 16 days, while the isolates of Trichinella from swine of Henan (central China) died at $-15^{\circ} \mathrm{C}$ for 12 months or at $-25^{\circ} \mathrm{C}$ within nine days (Xu, Cui et al., 1997). This suggest that $T$. nativa is a predominant species in dogs in the Northeast of China since their main biological characteristic is the resistance to freezing (Pozio \& La Rosa, 1991). Consequently, caution should be paid to the consumption of dog meat even if it had been frozen. Sufficient cooking of dog meat appears highly recommended to avoid transmission of trichinellosis to human.

\section{REFERENCES}

AN J.G. Report of an outbreak of trichinosis with nine cases. Journal of Yianbian Medical College, 1982, 5 (suppl.), 20.

CHIN Y.T. Trichinella infection in dogs, cats, rats, mice and pigs in Mukien, China. Peking National History Bulletin, 1950, 19, 297-300.

CUI J., WANG Z.Q., WU F. \& JIN X.X. Epidemiological and clinical studies on an outbreak of trichinosis in Central China. Annals of Tropical \& Medical Parasitology, 1997, 91, 481-488.

Deng Y.C. A survey of Trichinella infection of dog meats in Luoyang city. Henan Journal of Health and Anti-epidemic, $1978,1,38-40$.

Hou H.W., Jin Z.J., Sun J.F., Zheng M.G., Fu D.X., LANG W.Q., MA J.X., WANG M.Y., ZhENG Y.Y., Lu S.X. \& Bi N.S. A survey of an outbreak of trichinosis caused by eating roast dog meat. Chinese Journal of Preventive Medicine, 1983, 17 , 109-110.

HuANG F.C. Report of one case of human trichinosis. Chinese Journal of Internal Medicine, 1965, 13, 392.

Jiang H.F., Bai Y.T., Wang J.W., Meng Y.L., GaO F.L., Yu J.S. \& YANG X.W. Report of nine cases of trichinosis caused by eating dog meat. Journal of Postgraduates of Medicine, 1989, 9, 9.

Kapel C.M.O., Henriksen S.A, \& NAnsen P. Prevalence of Trichinella nativa in Greenland according to zoogeography, in: Trichinellosis. Ortega-Pierres A., Gamble H.R., van Knapen F. \& Wakelin D. (eds). Proceedings of the 9th International Conference on Trichinellosis. Centro de Investigacion y Estudios Avanzados del Instituto Politecnico Nacional, Mexico, D.F. Mexico, 1996, 591-597.
Khamboonnuang C. The present status of trichinellosis in Thailand. Southeast Asia Journal of Tropical Medicine and Health, 1991 (suppl), 312-315.

KIM C.M. The significance of changing trends in trichinellosis. Southeast Asia Journal of Tropical Medicine and Health, 1991 (suppl), 316-320.

La Rosa G., Pozio E., Rossi P. \& Murrell K. D. Allozyme analysis of Trichinella isolates from various host species and geographical regions. Journal of Parasitology, 1992, 78, 641-646

LI J.Z., MA W.C. \& LI C.X. A survey of dog trichinellosis in Chaoyang Region of Liaoning province. Chinese Journal of Veterinary Science and Technology, 1997, 27, 33.

LIU D.S. \& YU J.G. The discovery of Trichinella in Gansu province and the experimental study. Journal of Lanabou Medical College, 1960, 1, 93-98.

Liu M.Y., Song M.X., Yang R.F., Chen P.H., An C.L., Liu Z.S., GuO Z.B., Hou S.L., Lu Y.X. \& ZHU X.P. Identification of some China isolates of Trichinella by means of RAPD. Chinese Journal of Veterinary Science and Technology, 1997, $27,18-20$.

LIU S.H., Lu S.N., Yu Z. \& MENG Z.L. Study on the most suitable location for Trichinella inspection in frozen dog carcass. Chinese Journal of Animal Quarantine, 1996, 13, 4950.

Manson P. Trichina spiralis in Chinese pork. China Imperial Maritime Customs Medicine, 1880-1881, Report.

MENG D.G \& WANG M. Brief description of an outbreak of trichinosis. Chinese Journal of Preventive Medicine, 1995, 19, 305 .

PANG Y.K. \& ZHANG L.L. Data analysis of human trichinosis epidemic in Yunnan province from 1964 to 1997. Chinese Journal of Parasitology \& Parasitic Diseases, 1999, 17, 58-59.

Pozio E. \& LA Rosa G General introduction and epidemiology of trichinellosis. Southeast Asia Journal of Tropical Medicine and Health, 1991 (suppl.), 291-294.

ROCKIENE A. The Epidemiology of trichinellosis in Lithuania 1969-1992, in: Trichinellosis. Campbell W.C., Pozio E. \& Bruschi.F. (eds.), Proceedings of the Eighth International Conference on Trichinellosis. Istituto Superiore di Sanita Press, Rome, 1993, 539-544.

Wang H.J.\& Wang Q.Y. A survey of Trichinella infection in dogs. Chinese Journal of Animal Quarantine, 1992, 9, 28.

Wang P.S., Geng G.Y., Lai Z.M., Zhang J.S. \& Yu E.D. An outbreak of trichinellosis caused by eating dog meat. Chinese Joumal of Epidemiology, 1989, 10, 69.

WANG Z.Q., CuI J., Wu F. \& Jin X.X. Seven outbreaks of trichinosis in China during 1992-1996. Journal of Egyptian Society of Parasitology, 1997, 27, 529-538.

Wang Z.Q., CuI J., Wu F., MaO FR. \& Jin X.X. Epidemiological, clinical and serological studies on trichinellosis in Henan province, China. Acta Tropical, 1998, 71, 255-268.

WEI T.T. \& SONG L.P. Treatment of 17 cases of trichinosis with albendazole. Chinese Journal of Zoonoses, 1991, 7, 49.

Xu B.L., Cui Z.L., Zhang Y.L., LIN X.M. \& XIA S.L. Research report of the first finding of Trichinella nativa in China. Chinese Journal of Parasitology E Parasitic Diseases, 1997, 15, 257-262. 
Xu J.T., Wang J.Q., Ge L.M., Chen F.Y., Meng .F.R. \& Zhan S.Y. Investigation of an outbreak of trichinosis in a community. Chinese Journal of Parasitic Disease Control, 1991, 4, 234.

Xu K.C., Liu M.Y., Song M.X., Chen P.H., An C.L., Zheng M.G, ZHOU Z.J. \& CHEN Q.C., Identification on Trichinella from China by polymerase chain reaction. Chinese Journal Veterinary Science, 1997, 17, 467-469.

YANG GY., YANG H. \& YANG X. Veterinary examination of dog trichinellosis. Chinese Journal of Meat Hygiene, 1997, 2, 1819.

YANG H.M. Studies on epidemiology and control of trichinosis in Yunnan province. Chinese Journal of Parasitology $\varepsilon$ Parasitic Diseases, 1991, (Special Issue of Nationwide Survey on the Distribution of Parasites), 79-82.

Ye J.J., Zhang S.Q., Chen S.L., Sheng X.D. \& Pei S.J. Investigation on infection of the human Trichinella spiralis in Hubei province. Chinese Journal of Parasitic Disease Control, 1998, 11, 111-113.

Yuan H.J. Investigation of an outbreak of human tnchinosis. People's Military Surgeon, 1980, 4, 32-34.

Yugawa T. Trichina found in dogs in South Manchuna. Journal of Oriental Medicine, 1934, 21, 88.

ZHANG G.H. Investigation on Trichinella spiralis infection of meats sold at markets in Kunming. Journal of Parasito$\log y$ \& Parasitic Diseases, 1985, 3, 275.

Zhang Z.S. Trichinella spiralis, in: Human Parasitology. Zhao W.X. (eds), People's Health, Beijing, 1983, 585-599.

Zhou Y.C., Wang Y.Q., Xu S.K., Zheng J.X. \& Li S.S. A survey of parasitic helminthes of dogs and cats in HeilongJjiang. Chinese Journal of Zoonoses, 1990, 6, 61-62. 